\title{
REMOVAL OF POLLUTANTS FROM ABATTOIR WASTEWATER USING A PILOT-SCALE BAMBOO CONSTRUCTED WETLAND SYSTEM
}

\author{
Fidelis C. Nkeshita ${ }^{1 *}$, A. A. Adekunle ${ }^{1}$, R. B. Onaneye ${ }^{1}$, O. Yusuf ${ }^{1}$ \\ ${ }^{1}$ Federal University of Agriculture, Civil Engineering Department, Abeokuta, Nigeria \\ *E-mail of corresponding author: nkeshitafc@,funaab.edu.ng
}

\begin{abstract}
Wastewater from abattoir sources in urban areas can adversely affect the environment and cause health problems. This research investigated the ability of a bamboo constructed wetland system (BCWS) using Bambusa vulgaris, to treat wastewater from abattoir by removing nutrients and organics. This study adopted pilot scale reactors with bed dimension of 1 $m$ length $x 1 \mathrm{~m}$ width $x 1 \mathrm{~m}$ depth to simulate a horizontal sub-surface flow constructed wetland and planted with six strands of bamboo plants. Parameters analyzed include the nutrients (in the form of phosphate and nitrate) and the organics (in the form of Chemical oxygen demand, COD and Biochemical oxygen demand, BOD). The effluent analysis that were carried out within a 28-day retention period showed that there was a very good decrease in the nutrient pollutant parameters; phosphate $(99.6 \%)$, nitrate $(98.5 \%)$. The organics showed a lesser performance with a $39.3 \%$ removal efficiency for COD and $49.9 \%$ removal efficiency for BOD. Bamboo can be used in a BCWS for low cost green technology in urban areas and can be improved upon by increasing the number of bamboo shoot in order to have a larger root system.
\end{abstract}

Keywords: abattoir, phytoremediation, constructed wetland, bamboo.

\begin{tabular}{c}
\hline Received: $13.4 .2020 . /$ Accepted: 10.7.2020. \\
Published online: 7.12.2020. \\
\hline $\begin{array}{c}\text { Original scientific paper } \\
\text { https://doi.org/10.37023/ee.7.2.4 }\end{array}$
\end{tabular}

\section{INTRODUCTION}

Water is one of the most abundant natural resources needed for anthropogenic activities, however, its occurrence does not translate to ready availability for man's use. This is because more than $90 \%$ of the world's water can be found in oceans and seas and therefore saline in nature thus leaving only about $1 \%$ to be available for domestic, industrial, and other uses. The UN estimates that by $2050 \mathrm{AD}$, more than two billion would be added to the world population (UN News Centre 2012). Developing countries are perpetually faced with the problem of release of wastewater into receiving water bodies in urban areas thereby altering the biodiversity and introducing algal populations which hampers water supply for domestic uses (Smith et al. 1999). The reuse of wastewater constitutes a very vital aspect of the sustainability of water resources because it can be recycled after treatment to ensure the removal of pathogens and pollutants and protect humans from health defects (Grant 2011). The treatment process can be carried out naturally or in artificial treatment systems. Some of the systems that can be used to remove pollutants from wastewater include microbial fuel cells, anaerobic sludge blanket, electrocoagulation, and constructed wetland.

Constructed wetlands (CW) are artificial green technology that are designed and constructed to remove pollutants by simulating a natural process that occur in wetlands under natural conditions. The treatment processes that occur in $\mathrm{CW}$ are physical, chemical and biological in nature and include suspended particles settlement, oxidation of organic matter, photolysis, and microbial communities, mineralization and uptake of plants (phytoremediation), etc.(Badejo et al. 2018; Home \& Muthigo 2013).

Phytoremediation involves the use of plants to extract or remove pollutants. It is environmentally friendly and ensure Plants remove harmful chemicals when their roots take in water and nutrients from polluted streams, and groundwater (Baah 2011). It can remove pollutants using five different mechanisms; phytostabilization, rhizosphere bioremediation, phytoextraction, and rhizofiltration (Mudgal et al. 2010; Aisien et al. 2010; Badejo et al. 2018).

Bambusa vulgaris, a common bamboo plant in Nigeria is an open-clump type bamboo species. It is also native to China and Madagascar. Among bamboo species, it is one of the largest of its species. It has certain attractive features such as a good growing rate, high biomass production ability to deal with different environmental conditions and also adaptation to survive in some polluted areas such as mines (Chen et al. 2015). Just like other species of bamboo, it has a high accumulation rate in roots and is more than in shoots, stems, and leaves (Liu et al. 2015). Rajkumar et al. (2012) reported that this specie has high biomass production and fast-growing rates are the dominant characteristics that facilitate phytoremediation. 
Abattoir are structures that are used to slaughter animals for food for humans. The carcass and other wastes generated from the animal slaughter are often disposed of in flowing streams located around neighbourhoods where there are residential buildings in urban areas. Domestic utilization of these wastewater sources as well as the flow of the effluent into water bodies can adversely affect the environment and cause public health problems. In Abeokuta, there are many abattoirs within the city one of which is located at Alade-sanmi area along the Abeokuta-Ibadan expressway which was where the wastewater samples were collected. Abattoirs are generally known all over the world to pollute the environment either directly or indirectly from their various processes (Adelegan 2002).

The study investigates the development of a constructed wetland system (CWS) to remove pollutants from an abattoir with a bamboo specie, Bambusa vulgaris and also to evaluate the performance of the system.

\section{MATERIALS AND METHODS}

The wastewater sample was collected in a stream located in close proximity to the abattoir located in the Aladesanmi area of Abiola way off the Abeokuta-Ibadan express way in Abeokuta south local government area of Ogun state, Nigeria with a latitude of N709'51.696" and longitude of E3022'33.12048'. The samples were collected using a grab sample method of wastewater collection into ten 25 litres containers.

Young plants of Bambusa vulgaris were nurtured at the nursery in Funaab-Leventis farm, regularly irrigated and monitored for maturity to facilitate proper growth for ten (10) weeks after which six of it were transplanted into one of the pilot scale tanks located behind the Civil Engineering building, Federal University of Agriculture, Abeokuta, Nigeria so as to enable it become acclimatized with the new environment for two weeks. The plants were irrigated regularly with water from a nearby borehole source to enhance its growth.

Two pilot scale tanks with dimensions $1 \mathrm{~m} * 1 \mathrm{~m} * 1 \mathrm{~m}$ were used for the study to simulate a horizontal subsurface flow constructed wetland in which one was used as the bamboo reactor while the other was used as the control. Each tank was filled with 125 litres of abattoir wastewater. Each tank has a valve connected to an outlet at the bottom designed to collect the water samples for analysis. The path of flow was by gravity.

Water samples were collected in triplicates using sample bottles that were earlier washed in detergent, rinsed in distilled water, and subsequently rinsed with the sample before being taken to the laboratory for analyses. The collection of samples was done on a 7, 14, 21, and 28-day hydraulic retention periods (Badejo et al. 2012). The effectiveness of treatment in this research were observed from the nutrient removal (in terms of phosphate and nitrate) and organics removal (in terms of chemical oxygen demand, COD and biochemical oxygen demand, BOD) which were determined in the laboratory using standard analytical procedures as described by APHA (1998).

\section{RESULTS AND DISCUSSION}

The characterization of the initial water samples collected were adopted as values on the 0th day. The charts shown below in the figures indicate the performance of both pilot scale reactors for the $0,7,14,21$, and 28-day retention periods. From the results obtained, the young bamboo plants showed ability for phytoremediation of the abattoir wastewater.

\subsection{Nutrient removal}

Two nutrients were observed in this research which include Phosphorus in terms of phosphate and Nitrogen in terms of nitrates. The phosphate content before treatment in the reactor was about $6.04 \mathrm{mg} / \mathrm{l}$ as shown in Figure 1 but after a 28-day retention period, the concentration decreased to $0.02 \mathrm{mg} / \mathrm{l}$ thus indicating a $99.6 \%$ removal efficiency. The reactor also showed the ability to remove over $65 \%$ of phosphate in the first two weeks of operation. The successful ability of the reactor to achieve the removal efficiency may partly be due to the substrate that was used as the sorption property of sand used to fill the reactor could have had a big influence on the removal of phosphate which is further buttressed from the performance of the control. However, when compared to both reactors of control and the reactor, it showed the very good bamboo constructed wetland system's ability for phosphate removal (Michal et al. 2018; Vymazal 2004; Saeed \& Sun 2013) 


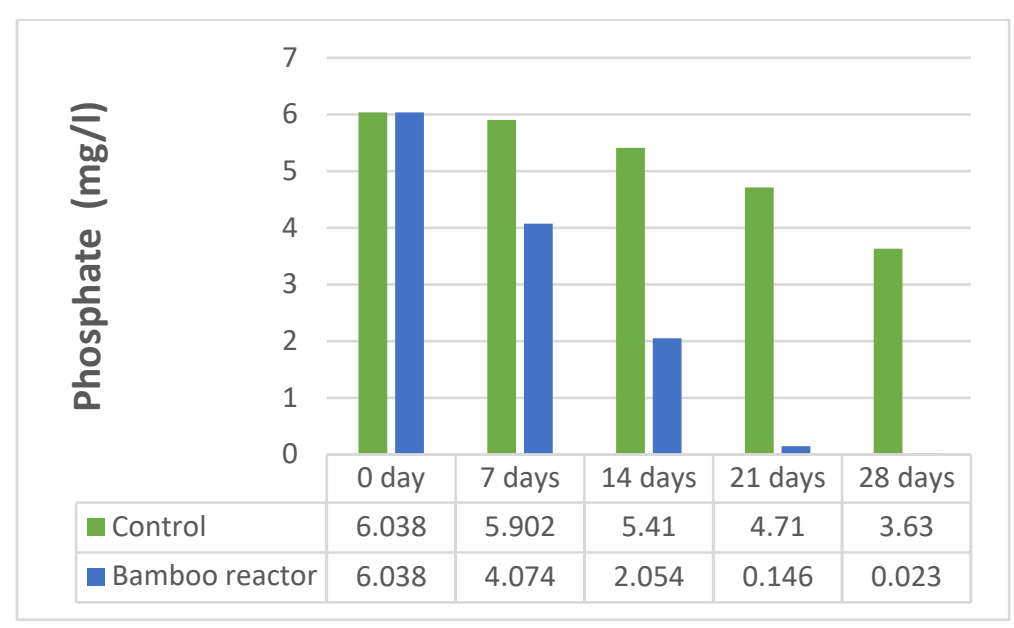

Figure 1. Retention period for phosphate removal

There was a reduction in the nitrate concentration at the end of the experiment from $21.12 \mathrm{mg} / \mathrm{l}$ to about 0.31 $\mathrm{mg} / \mathrm{l}$ as shown in Figure 2 thus accounting for about $98.5 \%$ reduction with over $60 \%$ of it removed by the end of the second week. This is higher when compared to the nitrate removal efficiency of Canna $s p$. as previously reported (Winanti et al. 2017). The high percentage removal could be attributed to the degradation of the abattoir wastewater and an adequate nitrification process within the bamboo construction wetland system. The bamboo constructed wetland system probably activated the conversion of ammonium in the wastewater to nitrates by Nitrosomonas bacteria (Fan et al. 2013; Yuan et al. 2016) and was subsequently absorbed by the bamboo to further undergo the process of conversion to nitrogenous oxides by chemo autotrophic bacteria (Vymazal 2007; Saeed \& Sun 2013).

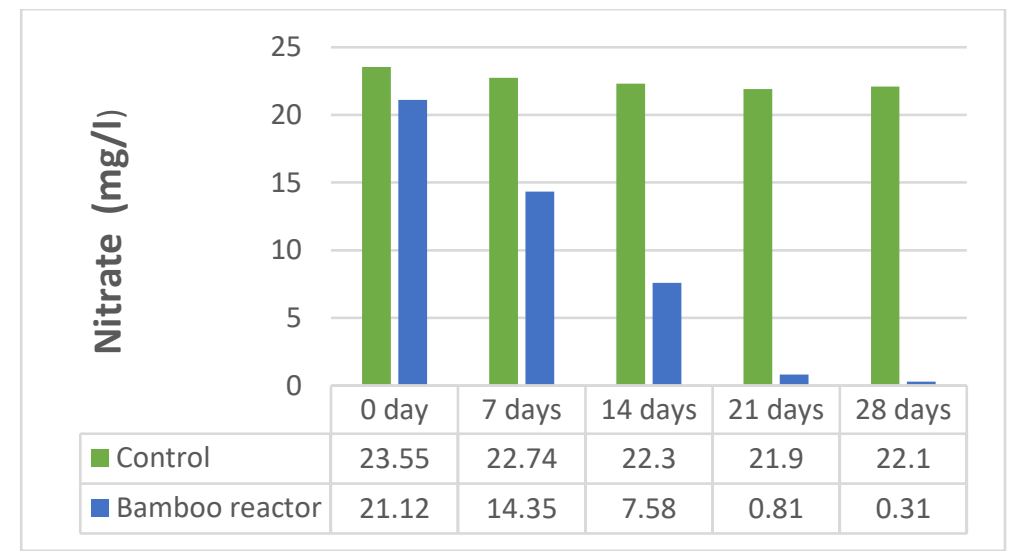

Figure 2. Retention period for nitrate removal

\subsection{Organics removal}

The chemical oxygen demand (COD) content decreased from a concentration of $4971.1 \mathrm{mg} / \mathrm{l}$ to $3018 \mathrm{mg} / \mathrm{l}$ within the 28-day retention time as can be seen from Figure 3 thus, accounting for almost $39.3 \%$ of the removal efficiency. The relatively low number of shoots and corresponding root system may have played a role thereby leading to a non-optimal organic biodegradation. Bacteria plays an influential role in COD and may have shown a less prominent influence more than the vegetation considering that the bamboo plants are relatively young (Akratos \& Tsihrintzis 2007; Camacho et al. 2007). The bacterial role was to ensure microbial decomposition when the matrix layer was adsorbed to the plant roots. This mechanism may have resulted from the production of oxygen by photosynthesis in the leaves and routed to the root system to enable bacteria to flourish and degrade the organic content (Yang et al. 2007; Sawaittayothin \& Polprasert, 2007). 


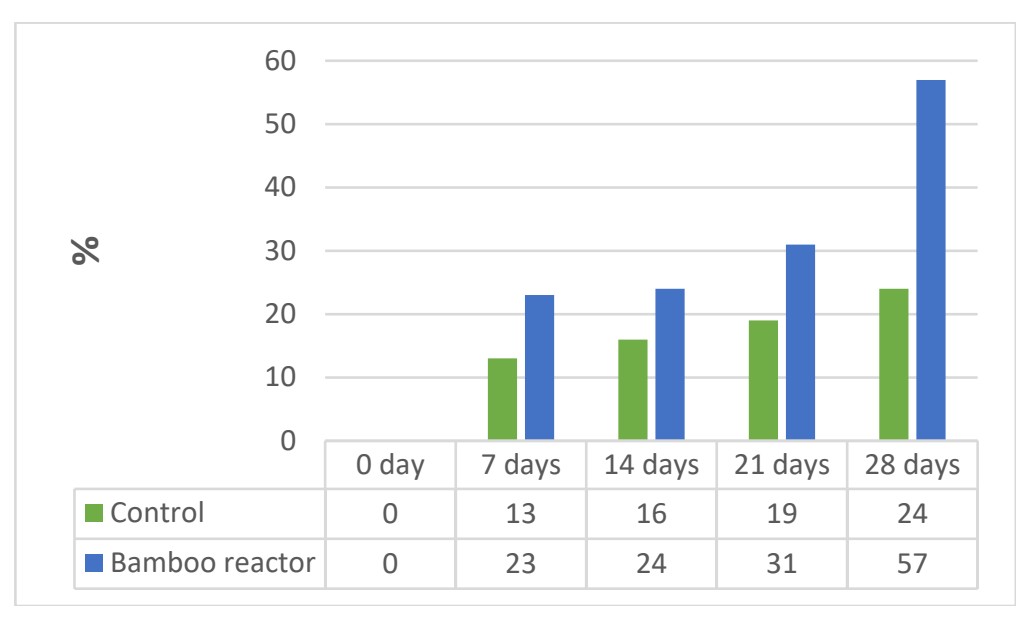

Figure 3. Retention period for COD removal

From Figure 4, BOD decreased from $2144.35 \mathrm{mg} / \mathrm{l}$ to $1075 \mathrm{mg} / \mathrm{l}$ signifying $49.9 \%$ removal efficiency. The high organic load may have been too much for the bamboo plants to bear and therefore may have resulted in nonoptimal biological processes of organics and subsequent unfinished adapting process of the plants in the new media of constructed wetland system. However, the bamboo reactor performed well when compared to the control and it is possible that for such young plants, further retention time may further increase the removal efficiency. When compared to the results of some researchers it could be seen that $22 \%$ removal efficiency was achieved when Typha angustifolia was used (Katsenovich et al. 2009), a $52 \%$ BOD was achieved during the treatment of secondary wastewater, in Mexico, with Typha latifolia and Phragmites australis (Rivas et al. 2011).This is not to overrule the fact that other systems have been able to achieve very high BOD removal efficiencies of more than $85 \%$ (Chang et al. 2012; Saeed et al. 2012; Abou-Elela et al. 2014).

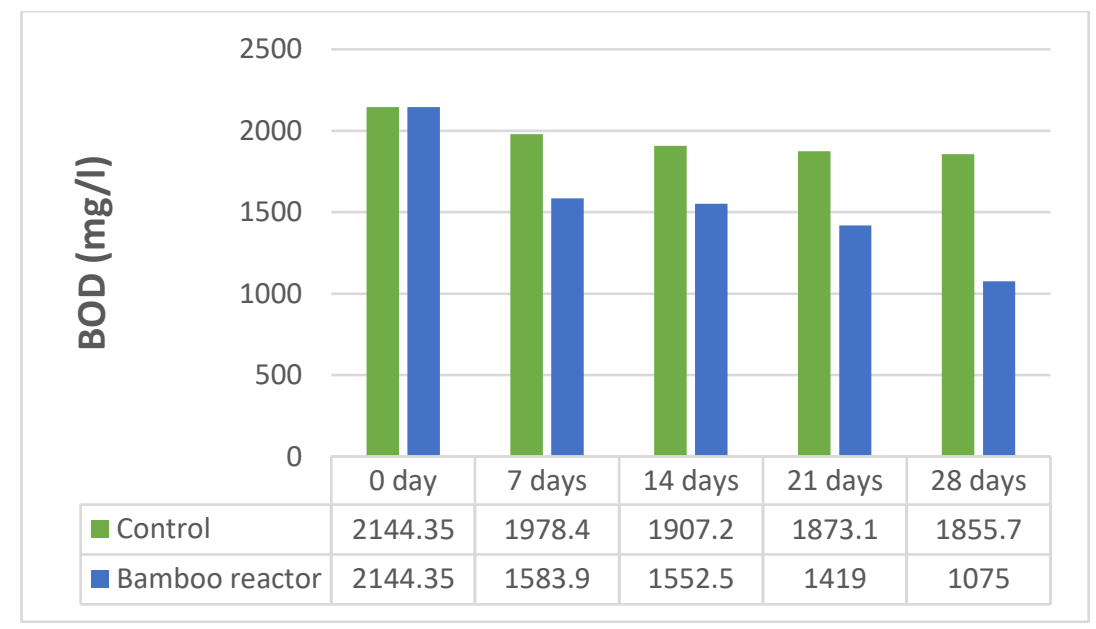

Figure 4. Retention period for BOD removal

\section{CONCLUSION}

This paper investigates the ability of a pilot scale bamboo constructed wetland system to treat wastewater from abattoir. Results show that under 28-day retention time, the bamboo constructed wetland system achieved up to $99.6 \%$ phosphate removal, $98.5 \%$ nitrate removal but performed poorly in the COD removal efficiency of about $39.3 \%$ but fairly in the BOD removal efficiency of $49.9 \%$. This CWS could be used for field applications in urban areas if the number of bamboo shoots are increased in order to create a more effective root system.

\section{REFERENCES}

Abou-Elela SI, Golinelli G, El-Tabl AS and Hellal MS (2014) Treatment of municipal wastewater using horizontal flow constructed wetlands in Egypt. Water Science and Technology, 69(1):38-47.

Adelegan J (2002) Environmental policy and slaughterhouse waste in Nigeria. Proceedings of the 28th WEDC conference Kolkata India, 3-6. 
Akratos CS and Tsihrintzis VA (2007) Effect Of Temperature, HRT, Vegetation And Porous Media On Removal Efficiency Of Pilot-Scale Horizontal Subsurface Flow Constructed Wetlands. Ecol. Eng. 29(2):173-91.

APHA (1998) Standard Methods for Examination of Water and Wastewater. 20th ed. American Public Health Association, Washington, DC, USA.

Baah B (2011) Phytoremediation of Hydrocarbon Contaminated Soil - A Case Study at Newmont Ghana Gold Limited - Ahafo Kenyasi, Kwame Nkrumah University of Science and Technology, Master Thesis, pp 100.

Badejo AA, Folorunsho TP, Nkeshita CF, Nwosu UG (2008) Phytoremediation of Cadmium using water hyacinth in surface flow constructed wetland. Nigerian Institution of Water Engineers $-2{ }^{\text {nd }}$ National Conference "Climate Change and Water Resources in Nigeria - Processes, Impacts and Adaptations" Abeokuta, October 15th 17 th 2018.

Camacho JV, De Lucas Martinez A, Gomez RG and Sanz JM (2007) A Comparative Study of Five Horizontal Subsurface Flow Constructed Wetlands Using Different Plant Species for Domestic Wastewater Treatment Environ. Technol. 28(12):1333-43.

Chang JJ, Wu SQ, Dai YR, Liang W and Wu ZB (2012) Treatment performance of integrated vertical-flow constructed wetland plots for domestic wastewater. Ecological Engineering, 44:152-159.

Chen J, Shafi M, Li S, Wang Y, Wu J, Ye Z, Peng D, Yan W and Liu D (2015) Copper induced oxidative stresses, antioxidant responses and phytoremediation potential of Moso bamboo (Phyllostachys pubescens). Scientific Reports. 4:135-54

Fan J, Liang S, Zhang B, and Zhang J (2013) A Review on Sustainability Of Constructed Wetlands For Wastewater Treatment: Design And Operation. Environ. Sci. and Poll. Research, 20(4):2448-52.

Grant CA (2011) Influence of phosphate fertilizer on cadmium in agricultural soils and crops. Pedologist, 54:143-155.

Home PG and Muthigo KG (2013) Assessment of The Efficiency of Different Mixes of Macrophytes in removing Heavy Metals from Wastewater Using Constructed Wetland. In Scientific Conference Proceedings.

Katsenovich YP, Hummel-Batista A, Ravinet AJ and Miller JF (2009) Performance evaluation of constructed wetlands in a tropical region. Ecological Engineering, 35(10):1529-1537.

Liu D, Li S, Islam E, Chen JR, Wu JS, Ye ZQ, Peng DL, Yan WB and Lu KP (2015) Lead accumulation and tolerance of Moso bamboo (Phyllostachys pubescens) seedlings: applications of phytoremediation. Journal of Zhejiang University SCIENCE B 16:123-130

Marzec M, Jóźwiakowski K, Dębska A, Gizińska-Górna M, Pytka-Woszczyło A, Kowalczyk-Juśko A, Listosz A (2018) The Efficiency and Reliability of Pollutant Removal in a Hybrid Constructed Wetland with Common Reed, Manna Grass, and Virginia Mallow. Water, 10:1445.

Mudgal V, Madaan N and Mudgal A (2010) Heavy metals in plants: Phytoremediation: Plants used to remediate heavy metal pollution. Agri. Biol. J. Am. 1(1):40-46.

Rajkumar M, Sandhya S, Prasad MNV, Freitas H (2012) Perspectives of plant-associated microbes in heavy metal phytoremediation. Biotechnology Advances, 30(6):1562-1574

Rivas A, Barcelo-Quintal i and Moeller GE (2011) Pollutant removal in a multi-stage municipal wastewater treatment system comprised of constructed wetlands and a maturation pond, in a temperate climate. Water Science and Technology, 64(4):980-987.

Saeed T, Afrin R, Muyeed AA and Sun G (2012)Treatment of tannery wastewater in a pilot-scale hybrid constructed wetland system in Bangladesh. Chemosphere, 88(9):1065- 1073

Saeed T, Sun G (2013) A lab-scale study of constructed wetlands with sugarcane bagasse and sand media for the treatment of textile wastewater. Bioresour. Technol. 128:438-447.

Sawaittayothin V and Polprasert C (2007) Nitrogen Mass Balance And Microbial Analysis Of Constructed Wetlands Treating Municipal Landfill Leachate. Bioresource Technol. 98(3):565-70

Smith AH, Lopipero PA, Bates MN and Steinmaus CM (2002) Arsenic epidemiology and drinking water standards. Science 296(21):2145-2146.

UN news (2012) Available via https://news.un.org/en/story/2012/12/428692-year-end-news-conference-banflags-uns-challenges-and-successes-tumultuous-2012.

Vymazal J (2004) Removal of phosphorus in constructed wetlands with horizontal sub-surface flow in the Czech Republic. Water Air Soil Pollut. 4:657-670. 65

Vymazal J (2007) Removal Nutrients In Various Types Of Constructed Wetlands. Sci.Tot. Environ. 380:48-

Winanti ET, Rahmadyanti E and Fajarwati IN (2018) Ecological Approach of Campus Wastewater Treatment using Constructed Wetland. IOP Conf. Series: Materials Science and Engineering, 288, 012062

Yang Q, Chen ZH, Zhao JG and Gu BH (2007) Contaminant Removal Of Domestic Wastewater By Constructed Wetlands: Effects Of Plant Species J. Integ. Plant Bio. 49(4):437-46.

Yuan J, Dong W, Sun F, Zhao K, Du C and Shao Y (2016) Bacterial Communities And Enzymatic Activities In The Vegetation-Activated Sludge Process (V-ASP) And Related Advantages By Comparison With Conventional Constructed Wetland. Bioresource Technol. 220:341-8 